\title{
GIS-BASED ESTIMATION OF WETLAND CONSERVATION POTENTIALS IN EUROPE
}

\author{
SCHLEUPNER, C.* - SCHNEIDER, U.A. \\ Research Unit Sustainability and Global Change, Center for Marine and Atmospheric Science \\ Bundesstrasse 55, 20146 Hamburg, Germany \\ (phone: +49-40-42838-7071; fax: +49-40-42838-7009) \\ *Corresponding author \\ e-mail: christine.schleupner@zmaw.de \\ (Received $2^{\text {nd }}$ June 2009; accepted $10^{\text {th }}$ February 2012)
}

\begin{abstract}
In the EU different utilization demands compete with each other and space is limited. As a consequence, socio-economic considerations and economic activities play therefore an important part in land use management and conservation planning. Often the integration of conservation concerns in agricultural as well as forestry production land use models has been neglected. One reason is a lack of accurate and consistent basis data. Therefore, conservation studies that offer high-accuracy landscape information at the European level are often recommended by policy makers, but rarely realized. This study contributes to this problem by creating and preparing a wetland distribution model (SWEDI) for integration into the mathematical bottom-up land use assessment model EUFASOM, which studies synergies and tradeoffs between biodiversity conservation efforts, greenhouse gas mitigation options, as well as traditional agriculture and forestry. The basis of SWEDI is the optimal combination of existing spatial datasets to obtain the spatial distribution of wetlands by definition of flexible knowledge rules. The model distinguishes between existing wetlands and sites suitable for wetland restoration at $1 \mathrm{~km}$ resolution. It differentiates several wetland types and covers the whole EU-25 area. The results of the model may help to locate sites suitable for restoration programs, or for the introduction of faunistic corridors.
\end{abstract}

Keywords: land use planning, restoration ecology, spatial analysis

\section{Introduction}

Because of its settlement history, land utilization in Europe is diverse and complex. As a consequence, many natural ecosystems as wetlands are altered and experience degradation, fragmentation and loss. It is estimated that more than two thirds of all wetlands in Europe have been lost since beginning of the $20^{\text {th }}$ century (LIFE, 2007) because economically profitable land utilization requires drainage of the wetlands. Today, wetlands are considered to be among the world's most threatened ecosystems. Besides biotope reduction and habitat fragmentation wetland loss has been also made responsible for unprecedented flooding events and species declines (Dahl, 2006). Because of natural habitat shortage latest conservation efforts include the option of restoration and creation of wetlands to meet the targets set out by the European Commission to halt biodiversity decline. But changing land use for food and, increasingly, biofuel production constitutes a great challenge to nature conservation. Conservationists are concerned that the promotion of bioenergy plantations in the context of climate change mitigation policies could threaten nature reserves and would lead to further biotope loss.

In the past the integration of conservation concerns in agricultural as well as forestry production land use models has often been neglected (Franklin and Swanson, 2007). One reason is often a lack of accurate and consistent basis data. Therefore, conservation 
studies that offer high-accuracy landscape information at the European level are often recommended by policy makers, but rarely realized by researchers (Wascher, 2000; Klijn, 2002; Scott and Tear, 2007; Wiens, 2007).

Usually, economic land use models refer to country statistics as base data. These data differ in spatial accuracy, reliability, acquisition data and class definition. Aggregating statistical and spatial data from many sources into one database often causes low spatial accuracy and complicates comparability, especially between eastern and western European countries. So is the spatial distribution of wetlands in Europe not well known except for large wetland areas or for wetlands of special ecological interest (Merot et al., 2003). Even those wetland areas, which have been identified on the behalf of European Environment Agency (EEA), correspond to wetland areas of ecological interest and represent only a rather small part of all wetland areas (Bernard, 1994). Some wetland studies modeled wetland distribution at global scales (Matthews and Fung, 1987; Aselmann and Crutzen, 1989; Stillwell-Soller et al., 1995; Joint Research Centre, 2000; Lehner and Döll, 2004). Due to its global perspective, the spatial resolution is coarse and wetlands are seldom differentiated in detail what makes the use of these data for conservation studies in European scale inappropriate. The most detailed consistent information about wetland habitats in Europe offers the EUNIS (European Nature Information System) Database with the distinction of over 2600 terrestrial habitat classes at the fourth level (Moss and Davies, 2002 a,b). However, the corresponding EUNIS habitat type map (European Topic Centre on Biological Diversity (ed.)) that has been created using mainly aggregated CORINE data refers only to the first level $(=10$ major habitats) of the EUNIS habitat classification. Also, the CORINE biotopes data (European Commission, 1991; Moss and Wyatt, 1994; Moss et al., 1996; EEA, 2000a) that are based on reported NATURA2000 sites do not represent the existing wetlands completely and are only available in terms of spots on the map without area size statements. At present, the CORINE data (EEA, 2000b) is the most detailed land cover database covering the European Union. One disadvantage is the heterogeneity of the classes determined by functional land use and not by land cover itself. The digital map of the potential natural vegetation of Europe (Bohn and Neuhäusel, 2003) shows a detailed classification and potential distribution of wetland vegetation types across Europe. However, this distribution is irrespective of human influences and therefore only conditionally suitable because river regulation, peat extraction or urbanization on former wetland areas often lead to changed wetland restoration potentials. In all it becomes clear that there are no digital land cover or vegetation maps of the EU that show detailed wetland distribution.

This study contributes to this problem by compiling spatially consistent information on wetlands differentiated by wetland types and characteristics using GIS-based techniques. Not only existing wetland habitats should be documented but also potential wetland restoration sites by considering actual land use options. This way a new methodology on broad scale distribution modeling is developed. The study presented here is an attempt to extend the distribution modeling process to a broad continental scale by keeping the spatial accuracy as high as possible. This is important because European wetlands are often fragmented ecosystems of small extent. Many wetlands are smaller than one $1 \mathrm{~km}^{2}$. But improvements in data quality and availability as well as simplifications in earth observation techniques make the more detailed studies feasible. As a result the narrow stripes of alluvial forests or small isolated bogs may be better represented in broad-scale analyses of wetlands. Besides the importance of regional 
case studies, decision makers of European land use policies demand spatial ecosystem information at holistic scales. The resulting wetland distribution model is finally aimed to be integrated into the mathematical bottom-up land use assessment model EUFASOM (European Forest and Agricultural Sector Optimization Model), which is used to study synergies and trade-offs between wetland conservation efforts, greenhouse gas mitigation options including carbon sinks and bioenergy, and agriculture and forestry of Europe (Schneider et al., 2008). Through EUFASOM, economic wetland potentials for optimal land use options are determined under certain policy scenarios.

\section{Methods}

\section{Definition of wetlands}

Often wetland terms and definitions are not standardized. The RAMSAR Convention (Article 1.1) defines wetlands as "areas of marsh, fen, peat land or water, whether natural or artificial, permanent or temporary, with water that is static or flowing, fresh, brackish or salt, including areas of marine water the depth of which at low tide does not exceed six meters". In wetlands water is present at or near the surface of the land also if only for varying periods of the year. Wetlands vary widely in soil, topography, climate, hydrology, water chemistry, vegetation, and other factors, also because of human disturbance (Pott and Remy, 2000; Dierssen and Dierssen, 2001; Blume et al., 2002). In this study we concentrate on the natural freshwater or inland wetlands whose types are further defined in Table 1.

Table 1. Used wetland terms and their definitions, based on Cowardin et al.(1979), Mitsch (1994), Sanderson (2001)

\begin{tabular}{l|l}
\hline \multicolumn{1}{c|}{ Common Wetland Names } & \multicolumn{1}{c}{ Definition } \\
\hline Peatland & $\begin{array}{l}\text { generic term of any wetland that accumulates partially decayed } \\
\text { plant matter. } \\
\text { peat-accumulating wetland that has no significant inflows or } \\
\text { outflows. Water and nutrient input entirely through precipitation; } \\
\text { characterized by acid water, low alkalinity, and low nutrients. Peat } \\
\text { accumulation usually dominated by acidophilic mosses, particularly } \\
\text { sphagnum. } \\
\text { peat-accumulating wetland that receives some drainage from } \\
\text { surrounding mineral soil. Usually dominated by sedge, reed, shrub } \\
\text { or forest ( } \rightarrow \text { swamp forest). Surface runoff and/or ground water } \\
\text { have neutral pH and moderate to high nutrients. } \\
\text { in European terminology a marsh has a mineral soil substrate and } \\
\text { does not accumulate peat. Permanently or periodically inundated } \\
\text { site characterized by nutrient-rich water and emergent herbaceous } \\
\text { vegetation (grasses, sedges, reed) adapted to saturated soil } \\
\text { conditions. } \\
\text { any wetland that is dominated by forest. } \\
\text { wetland dominated by trees, most often forested fen. Depends on } \\
\text { nutrient-rich ground water derived from mineral soils. } \\
\text { Periodically inundated forest areas next to river courses. }\end{array}$ \\
$\begin{array}{l}\text { Wet forest } \\
\text { a. Swamp forest }\end{array}$ &
\end{tabular}

The definition of inland wetlands also includes marshes and wet meadows dominated by herbaceous plants that are most often human made as well as shrub- or tree- 
dominated swamps. In Europe, inland wetlands are most common on floodplains along rivers and streams, along the margins of lakes and ponds, and in other low-lying areas where the groundwater intercepts the soil surface or where precipitation sufficiently saturates the soil (vernal pools and bogs). Many of these wetlands are seasonal and may be wet only periodically. The freshwater wetlands denote the most relevant areas for land use options implemented in EUFASOM. Open waters are considered separately.

\section{Locating wetland potentials}

The spatial wetland distribution model "Swedi" is developed as extraction tool to denote wetland allocations in Europe. In this respect GIS and spatial modeling are used as instrument to locate existing wetland areas as well as to identify the most suitable areas for wetland regeneration measures. This GIS model aims to depict the distribution of wetland areas at regional level and also at coarse geographic scale. This involves the integration of a variety of GIS datasets and multiple iterations of expert review and interpretation to delineate the potential wetland areas of Europe. We used the GIS tool ArcGIS9 for analysis.

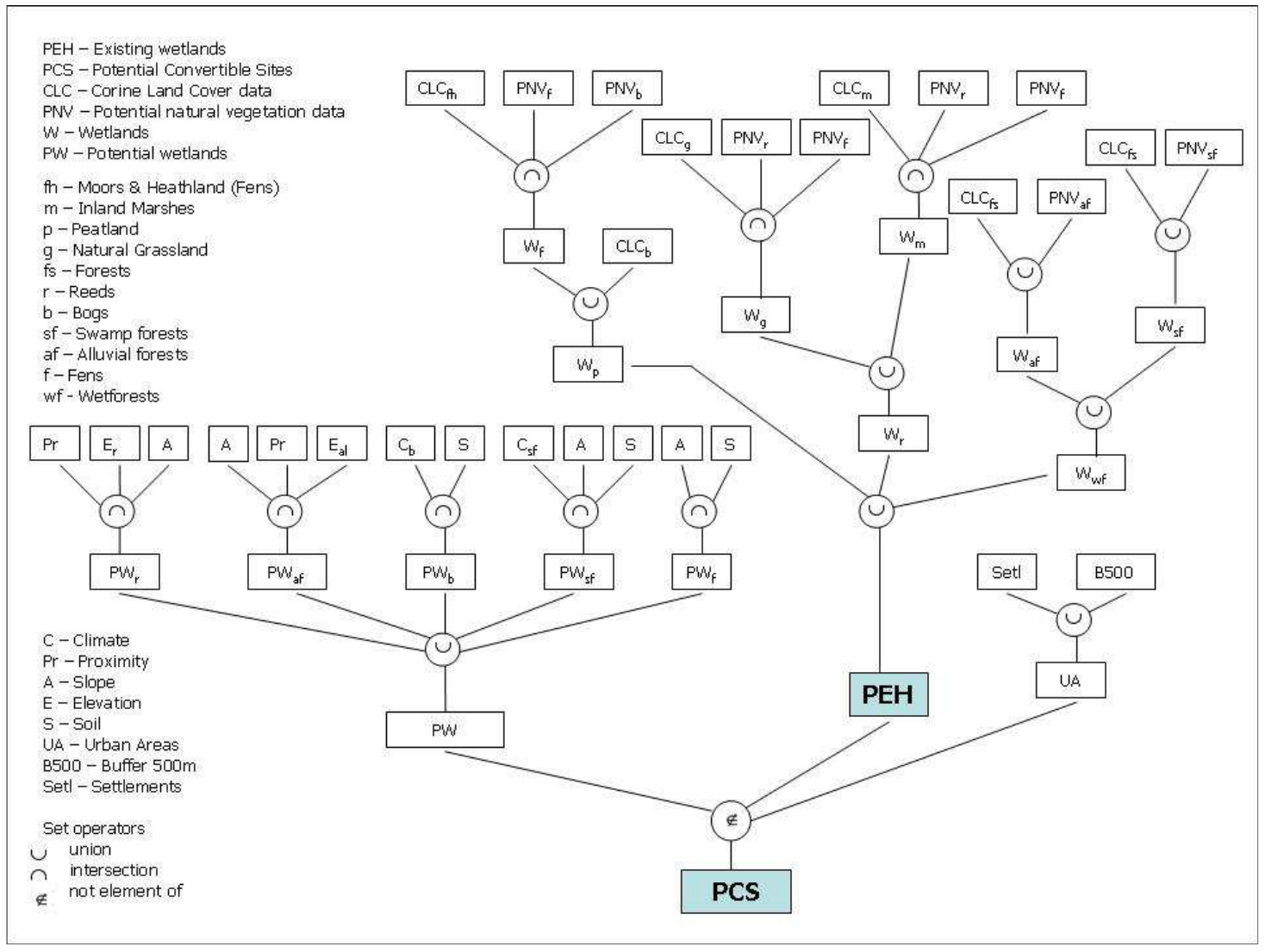

Figure 1. The spatial wetland distribution model "Swedi"

Figure 1 gives an overview of the Swedi (Spatial wetland distribution) model structure and its core input data. It is described in more detail in the following methodological section that is subdivided into two parts. The first deals with the evaluation of existing wetlands in Europe, and the second with the modeling of potential convertible sites for wetland restoration management. 


\section{Existing wetland habitats (PEH)}

Existing wetland biotopes are defined as areas where wetlands with state close to nature actually appear within Europe. The analysis is executed with Model Builder and the Spatial Analyst Extension of ArcGIS9. The Corine land cover map 2000 with spatial resolution of $100 \mathrm{~m}$ serves as core base map (EEA 2000b). From the CORINE data, the following land cover classes have been extracted: moors \& heathland (3.2.2.), inland marshes (4.1.1.), peat bogs (4.1.2.), inland waters and estuaries (5.1. and 5.2.2.), natural grassland (3.2.1.) and forests (3.1.). The EEA (1995) gives detailed definitions of each class. Within the spatial model the land cover class "peat bogs" serves as the only one that does not need to be altered to show existing "bog" wetlands, whereas all other selected land cover classes have to be split up separately: out of the generalized forest classes, only the wet forests, namely alluvial forests next to river courses and fen or swamp forests, are extracted through rule based statements using set operators. The CORINE classes "natural grassland" as well as "inland marshes" serve as base data for the model parameter "natural wet grasslands". In addition, moors, wet heaths and riverine and fen scrubs are extracted from the general class "moors and heathland". The map of the potential natural vegetation (PNV) of Europe (Bohn and Neuhäusel, 2003) has been selected as source to locate the wetland sites within these CORINE land cover classes. The PNV map in general distinguishes following wetland types: a. tall reed vegetation and tall sedge swamps, aquatic vegetation (PNV class R), b. mires (S), c. swamp and fen forests (T), d. vegetation of flood plains, estuaries and fresh-water polders and other moist or wet sites (U). These types can then be further subdivided. We extracted these wetland types and intersected them with the corresponding CORINE data. Only those sites matching both attributes were considered as present existing wetland site. The remaining sites were assumed to be non-wetland. However, this does not exclude the probability of the non-wetland areas to be potential wetland restoration sites as is explained in more detail below. Figure 2 gives examples of the intersection and extraction procedure.

In order to verify the accuracy of the distribution of existing wetlands in Swedi, resulting outputs must be compared with an independent data set (Verbyla and Litaitis, 1989; Araujo et al., 2005). A description of general CORINE Land Cover data accuracy is found in the EEA Technical Report 7 (2006). In this study we use the CORINE biotopes database and parts of the RAMSAR list of wetlands of international importance (2008) for comparative analyses. The Corine biotopes (Version 2000) database is an inventory of major nature sites. The aim of the database was to enhance reliable and accessible information about vulnerable ecosystems, habitats and species of importance as background information for community environmental assessment. The wetland sites of the database are - among others - attributed with the size of the wetland. Site coordinates are included for easy localization of the biotopes within a GIS. We selected 50 freshwater wetlands from the database and compared their occurrence in the Swedi model considering spatial accuracy and wetland size. The same procedure has been applied to 50 selected RAMSAR sites. Additionally, the spatial extends of denoted NATURA2000 wetland sites as well as available biotope maps of individual sites are compared to the existing wetlands of Swedi. 


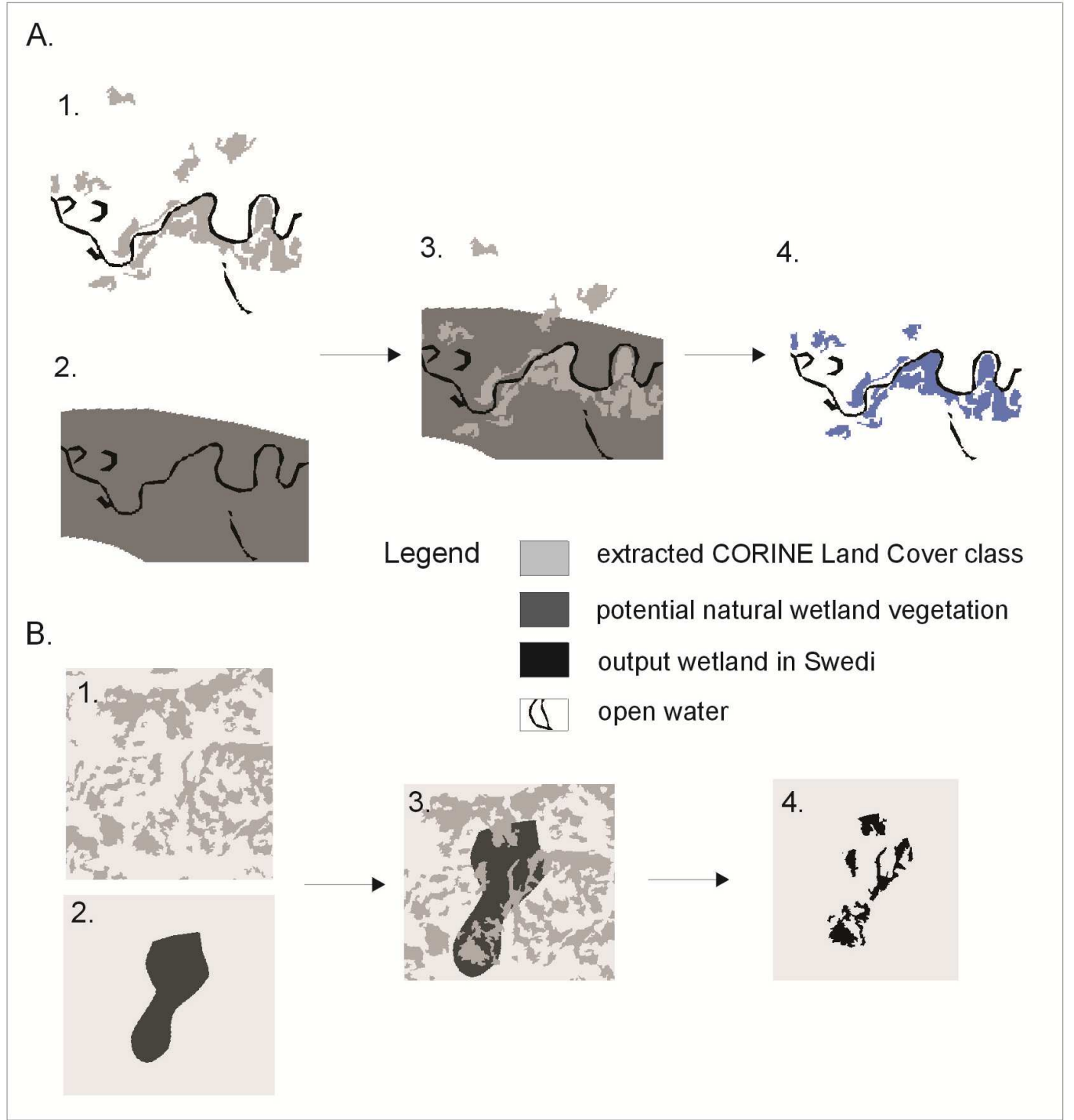

Figure 2. two regional examples showing the methodology of the extraction procedure A. for wetforests by intersection of extracted CORINE Land cover class "broad-leafed forest" with extracted "swamp and fen forests" (PNV class T) and "vegetation of flood plains, estuaries and fresh-water polders and other moist or wet sites" $(U)$ classes of the potential natural vegetation map of Europe. Shown is a section of the Elbe river between Dessau and Wittenberg / Germany. $B$. for moors, wet heaths and riverine and fen scrubs by intersection of extracted CORINE Land cover class "moors and heathland" with extracted "tall reed vegetation and tall sedge swamps, aquatic vegetation" $(R)$ and "mires" $(S)$ classes of the potential natural vegetation map of Europe. Shown is a region in the Grampian Mountains / Scotland

\section{Potential convertible sites (PCS)}

The second part of the GIS assessment evaluates potential convertible wetland sites. These areas may be used for location of restoration programs or habitat creational measures. The distribution of wetlands is explained by many dependent and explanatory variables. Important factors are the climatic, hydrological, geological, ecological and socio-economic conditions of the area. The classification of wetland distribution is therefore preferably based on analysis of these independent variables (Guisan and Zimmermann, 2000). The connection between the respective information of the 
database and the probable appearance of the wetlands is determined by assuming that there is a relationship between environmental gradients such as soil, climate, or slope and wetland distribution (Franklin, 1995). We use traditional statistical methods based on observed correlation as well as geographically weighted regression analysis to analyze environment-wetland relationships. This proved to be useful concerning European scale analyses, because it allows for regional differences in relationships by estimating regression parameters that vary across space (Miller et al., 2007). Characteristic soil parameters, climate conditions, slope angles, and elevations are worked out for every wetland type on the basis of several literature resources (Brinson, 1993; Kuntze et al., 1994; Ellenberg, 1996; Succow and Joosten, 2001; BfN, 2004). Through this, rule-based statements are derived about the potential appearance of the target wetland types. In combination with geographical data these statements allow the identification and localization of potential wetland sites within a GIS. Table 2 illustrates the resulting factors that characterize each wetland type.

Table 2. Rating factors that characterize each wetland type (after Brinson 1993, Kuntze et al. 1994, Ellenberg 1996, Succow and Joosten 2001, BfN 2004)

\begin{tabular}{l|c|c|c|c|c}
\hline & Soil & Slope Angle & Climate & $\begin{array}{c}\text { Proximity to } \\
\text { open waters }\end{array}$ & Elevation \\
\hline Fen & $\mathrm{X}$ & $\mathrm{X}$ & & & \\
Bog & $\mathrm{X}$ & & $\mathrm{X}$ & & \\
Swamp Forest & $\mathrm{X}$ & $\mathrm{X}$ & $\mathrm{X}$ & & \\
Alluvial Forest & & $\mathrm{X}$ & & $\mathrm{X}$ & $\mathrm{X}$ \\
Reeds & & $\mathrm{X}$ & & $\mathrm{X}$ & $\mathrm{X}$ \\
\hline
\end{tabular}

Former wetland areas are considered as most suitable for wetland recreation (Ellenberg et al., 1991; Wheeler et al., 1995; Schultlink and Van Vliet, 1997). These might be arable fields, pasture lands, fallow or forested areas on sites of former wetlands that have been intensely changed. Actual soil conditions might give hints for potential wetland biotopes. We use the European soil database (Joint Research Centre, 2004) of $1 \mathrm{~km}$ grid resolution and extract following potential wet- and peatsoil-classes: gleysols, fluvisols, gleyic luvisols, histosols, gleyic podzol. The wetland types bogs, swamp forests and fens are considered to be soil dependent (cf. table 2).

The climate parameter is only applied for the parameters bogs and swamp forests; all other wetland types are rated as azonal and therefore relatively climate independent (Succow and Jeschke, 1990; Ellenberg, 1996; Walter and Breckle, 1999). The climate variables of the wetland types shown in table 3 are extracted from the explanatory text of the map of the Natural Vegetation of Europe (BfN 2004) and are mainly based on Walter and Lieth (1967). We use the attributes temperature (max temp of warmest month, min temp of coldest month, average annual) and precipitation (average annual) of the Bioclim and Worldclim data at spatial grid resolution of 30 arc-seconds $(\sim 1$ $\left.\mathrm{km}^{2}\right)$. 
Table 3. Wetland type characteristics concerning their climate ranges of occurrence (after BfN 2004, Walter and Lieth 1967)

\begin{tabular}{l|c|c|c|c}
\hline Wetland type & $\begin{array}{c}\text { Average annual } \\
\text { temperature (in } \\
\left.{ }^{\circ} \mathbf{C}\right)\end{array}$ & $\begin{array}{c}\text { Average } \\
\text { precipitation } \\
(\mathbf{m m} / \mathbf{y e a r})\end{array}$ & $\begin{array}{c}\text { Max temp av. } \\
\text { warmest } \\
\text { month }\left({ }^{\circ} \mathbf{C}\right)\end{array}$ & $\begin{array}{c}\text { Min temp av. } \\
\text { coldest month } \\
\left({ }^{\circ} \mathbf{C}\right)\end{array}$ \\
\hline Bogs & $3-6$ & $300-1000$ & $12-17$ & $-15-(-2)$ \\
& $9-11$ & $1200-2000$ & $13-15$ & $5-7$ \\
& $3-8$ & $1400-2400$ & $10-12$ & $-2-0$ \\
& $5-9,5$ & $550-1500$ & $14-19$ & $-3-5$ \\
& $4-5,5$ & $900-1400$ & $11-12$ & $-3-0$ \\
& $3.5-7.8$ & $530-630$ & $17.5-19$ & $-10-(-2)$ \\
Aapa mires (fens) & $-10-1$ & $200-500$ & $8-13$ & $-25-(-10)$ \\
transitional mires & $-3-5$ & $250-700$ & $8-15$ & $-17-(-5)$ \\
(fens) & $0-5$ & $500-870$ & $8-14$ & $-12-(-3)$ \\
degraded bogs, & $8-9$ & $600-1200$ & $15-16$ & $0-4$ \\
now wet forests & & & & \\
wet forests & $6-11$ & $450-1000$ & $16-21$ & $-5-0$ \\
& $14-15$ & $>1000$ & $20-22$ & $6-8$ \\
& $9-10$ & $550-1000$ & $15-16$ & $4-5$ \\
\hline
\end{tabular}

The analyses of elevation dependent wetland types might also refer to climate or relief conditions (Merot et al., 2003). However, we are confined to the statements of highest occurrences of respective wetland types by the explanatory text of the PNV map of Europe (BfN 2004). The base elevation data for Europe are taken from GTOPO30 data a global digital elevation model at spatial resolution of 30 arc-seconds (sheets: W020N90, E020N90, W020N40, E020N40) (USGS 1996). In addition to that the biogeographical regions map of Europe (EEA 2002) contribute to the elevation parameter by dividing the height variables into several bioclimatic regions that better reflect the height-limits than country based distinctions of regions. Table 4 shows the wetland type characteristics concerning their maximum elevation occurrence range.

Table 4. Wetland type characteristics concerning their maximum elevation occurrence range (after Brinson 1993, Kuntze et al. 1994, Ellenberg 1996, Succow and Joosten 2001, BfN 2004)

\begin{tabular}{l|l|l}
\hline Wetland type & Biogeographical Region & Elevation (m) \\
\hline Reeds & Boreal, alpine (scand.) & $<=500$ \\
Reeds & Alpine (other), all others & $<=800$ \\
Alluvial forests & Boreal, alpine (scand.) & $<=500$ \\
Alluvial forests & Alpine (other), all others & $<=1200$ \\
\hline
\end{tabular}

The map of bio-geographical regions is based on the PNV map (Bohn and Neuhäusel, 2003). It distinguishes between six bio-geographical regions in the EU-25, namely Alpine, Boreal, Continental, Atlantic, Mediterranean, and Pannonian. Alluvial forests and reeds are considered elevation dependent, less because of climatic conditions, but more due to loss of suitable ground conditions (Ellenberg, 1996; Mulamoottil et al., 1996; BfN, 2004). The climate dependent wetlands are assumed to limit their height occurrence by this parameter itself. An elevation constraint is therefore not necessary. Only the fens are assumed neither climate nor elevation dependent. They solely refer to soil conditions and the slope parameter. 
The slope parameter is evaluated based on the elevation data using the Spatial Analyst extension of Arc GIS9. Only those areas with a slope angle below $1^{\circ}$ are assumed suitable for the wetland types reeds, alluvial forests, swamp forests and fens (Mulamoottil et al., 1996; Lyon, 2001). Due to scale reasons the slope angle is set to this maximum extension and does not distinguish slope angles below that point as has been done in case studies of larger scale (Tsihrintzis et al., 1998; Helmschrot and Flügel, 2002).

Also the proximity to inland waters or to existing inland peatland is an important criterion for localization of target areas if other parameters are fulfilled. The proximity criterion has been initially set to 500 meters. But this border may be handled flexible. For implementation in the GIS-based model we establish multiple ring buffers around inland waters and other bog areas with radius of the defined proximity. The extension of potential water surrounding wetland sites like alluvial forests can be detected by a combination of the proximity with other parameters.

Highly populated areas as are towns and cities provide very limited space for wetland restoration or construction. For this reason, potential convertible sites are only modeled for agriculturally used areas, grasslands and forests by using pseudo-absences for urban areas (cf. Chefaoui and Lobo, 2008). Urban areas including a buffer zone of 800 meters are omitted by the model. We use the Corine Land Cover 2000 data for determination of these sites.

For accuracy assessment the potential wetland sites are correlated with the spatial distribution of the existing wetlands. And in a last step, the existing wetland sites are subtracted from the preliminary results to obtain only data on potential convertible areas. All data encompass the whole EU-25 states boundaries with exception of Malta and Cyprus that are not included in the analysis.

\section{Results}

The comparison of existing wetlands with samples of the independent data sets (RAMSAR wetlands and CORINE biotopes) shows that all selected wetlands of the databases are also represented in Swedi. The differences lie in the area extent of the respective wetlands: In over $70 \%$ of the cases the model overestimates the size of an existing wetland. One reason is the fact that the existing wetlands module of the Swedi model accepts uncertainties about the state of the wetland ecosystem also due to scale reasons. We are not able to distinguish between afforestations or natural alluvial forests in a floodplain, for example, what also might lead to overestimation errors of the results. $26 \%$ of the sites are underestimated in size. The difficulty is the accurate demarcation of wetlands and its types from open waters and terrestrial land due to their dynamic characteristics and their fluctuating and undefined borders. Often open waters are integrated into the wetland definitions of the databases whereas these wetland types are considered separately in the Swedi model. However, more than $85 \%$ of the selected wetlands stay within the defined uncertainty range of $15 \%$ deviation. No significant differences in accuracy are found between northern and southern or eastern and western European wetlands. Figure 3 exemplarily shows a comparison of available spatial wetland data of Natura2000 with Swedi data as used for the accuracy assessment. Not all wetlands are implemented in the Natura2000 network and therefore it is reasonable that some existing wetlands of Swedi are not represented in the Natura2000 data. Also the spatial extend of the wetlands differ due to the fact that the wetland dimensions are 
difficult to define and that often the Natura2000 data include other biotopes combined in biotope complexes or buffer zones as well. However despite its inconsistencies in extent, more than $91 \%$ of the Natura 2000 wetlands data are also represented in Swedi.

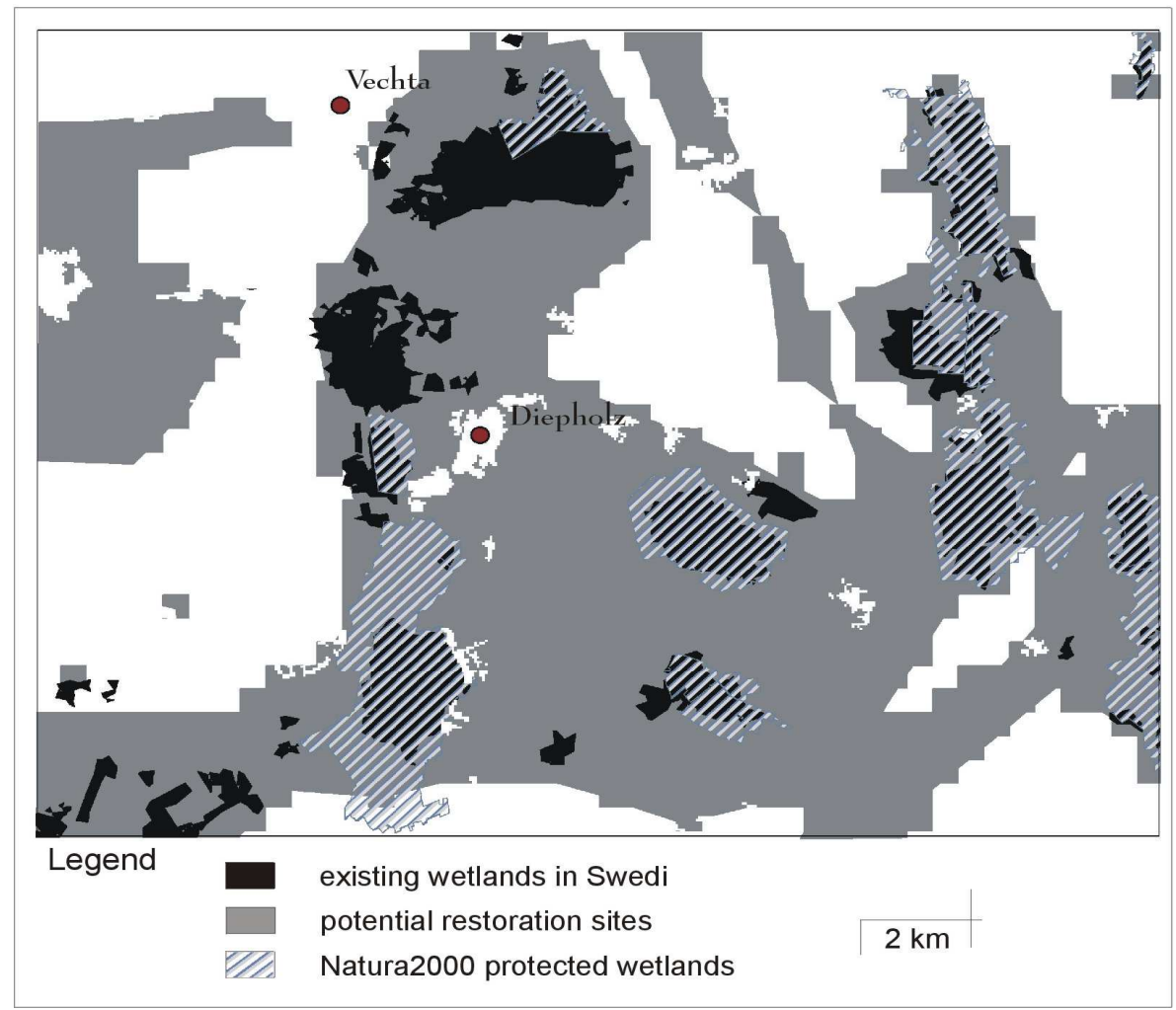

Figure 3. Example of the accuracy assessment in the case of the Dümmer Region in Lower Saxony / Germany. We used spatial information of wetlands implemented in the Natura2000 sites and correlated them to the wetland distribution of Swedi

Other comparisons with individual biotope maps on regional scale revealed more uncertainties and weaknesses of Swedi. This is due to the fact that wetlands below a certain extent are not well represented in Swedi and therefore some present wetlands may be underestimated or indicated as restoration site. At the same time the restoration sites overestimate the extent of potential wetland sites because of coarse base data in elevation or soil, for example, that do not respect geographic diversity at landscape scale. Under consideration of these limitations Swedi is only useful for general European scale studies.

Problems in comparability arose by drawing comparisons with a simple per-country aggregation of Swedi wetland areas to results of the Pan European Wetland Inventory (PEWI) (Nivet \& Frazier, 2004). This may simply be due to the fact that both datasets apply to different wetland type determinations and basis data. Whereas the Swedi data are spatially explicit and rely on other spatial and geophysical data, the PEWI data are on country scale and rely on different kinds of national wetland inventories or statistics. For this reason an accuracy assessment with PEWI data has been refused.

The outcomes of Swedi are spatially explicit data on wetland distribution in Europe. The results may be illustrated through wetland distribution maps. Figure 4 shows the spatial distribution of existing habitats (dark grey) and potential convertible sites (light 
grey) exemplarily for selected areas. The whole illustrated data set is available for download at http://www.fnu.zmaw.de/Dipl-Geogr-Christine-Schleupner.5728.0.html.

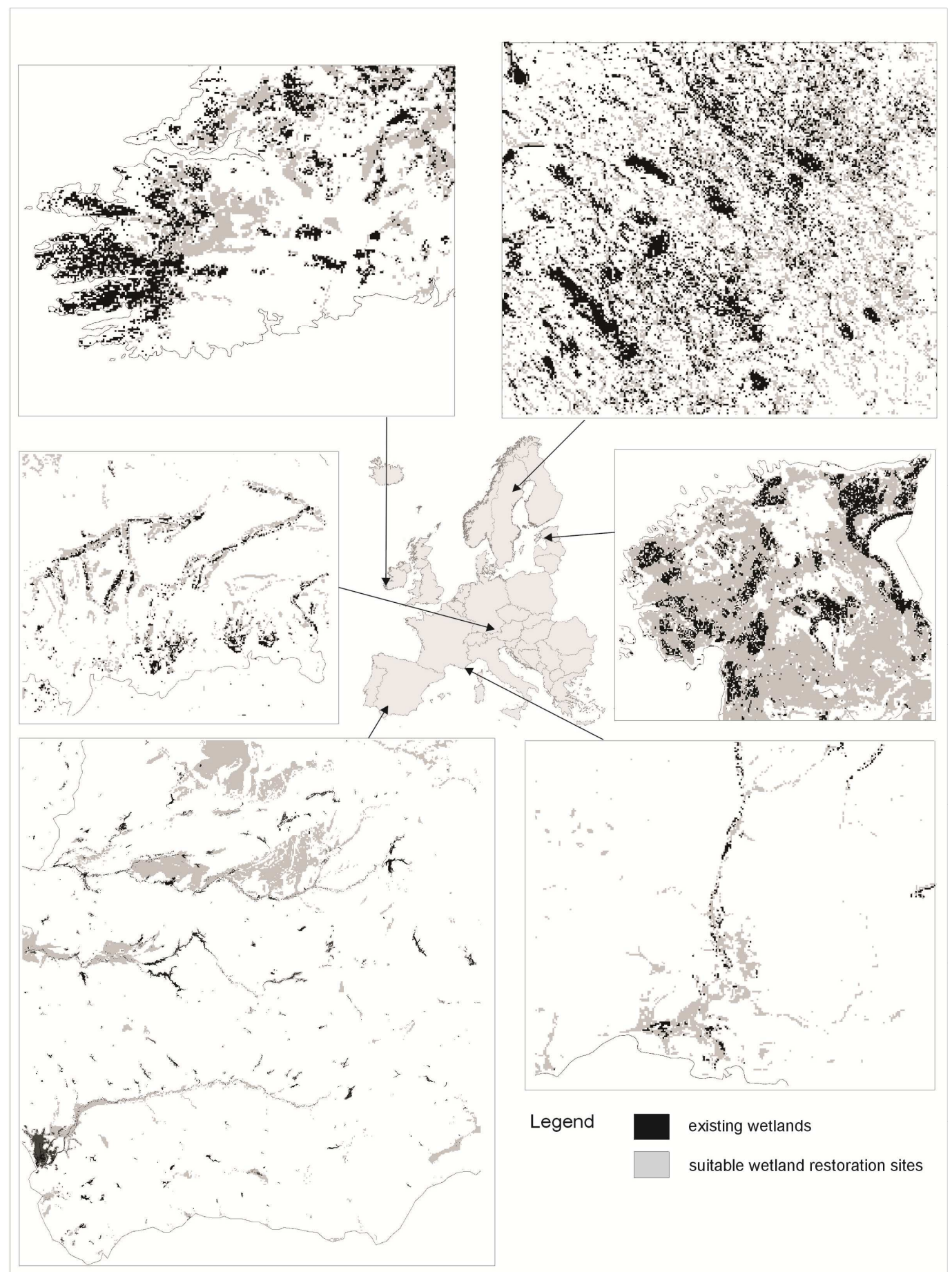

Figure 4. Detailed examples of the spatial distribution of potential existing habitats (dark grey) and potential convertible sites (light grey) of Swedi

An analysis of the Swedi map reveals that the majority of existing wetland areas $(\mathrm{PEH})$ is situated in the northern and western European countries, while the potential convertible sites (PCS) are well distributed over the EU. In total, about $4 \%$ of the EU-25 
land area consists of potentially existing wetlands and an additional $21 \%$ of the land areas are potential convertible to wetland sites. This constitutes a maximum share of wetlands of one fourth of the total land area of the EU-25. Figure 5 gives an general overview of the total area (in $1000 \mathrm{ha}$ ) of existing and the potential convertible wetland sites per country derived from Swedi.

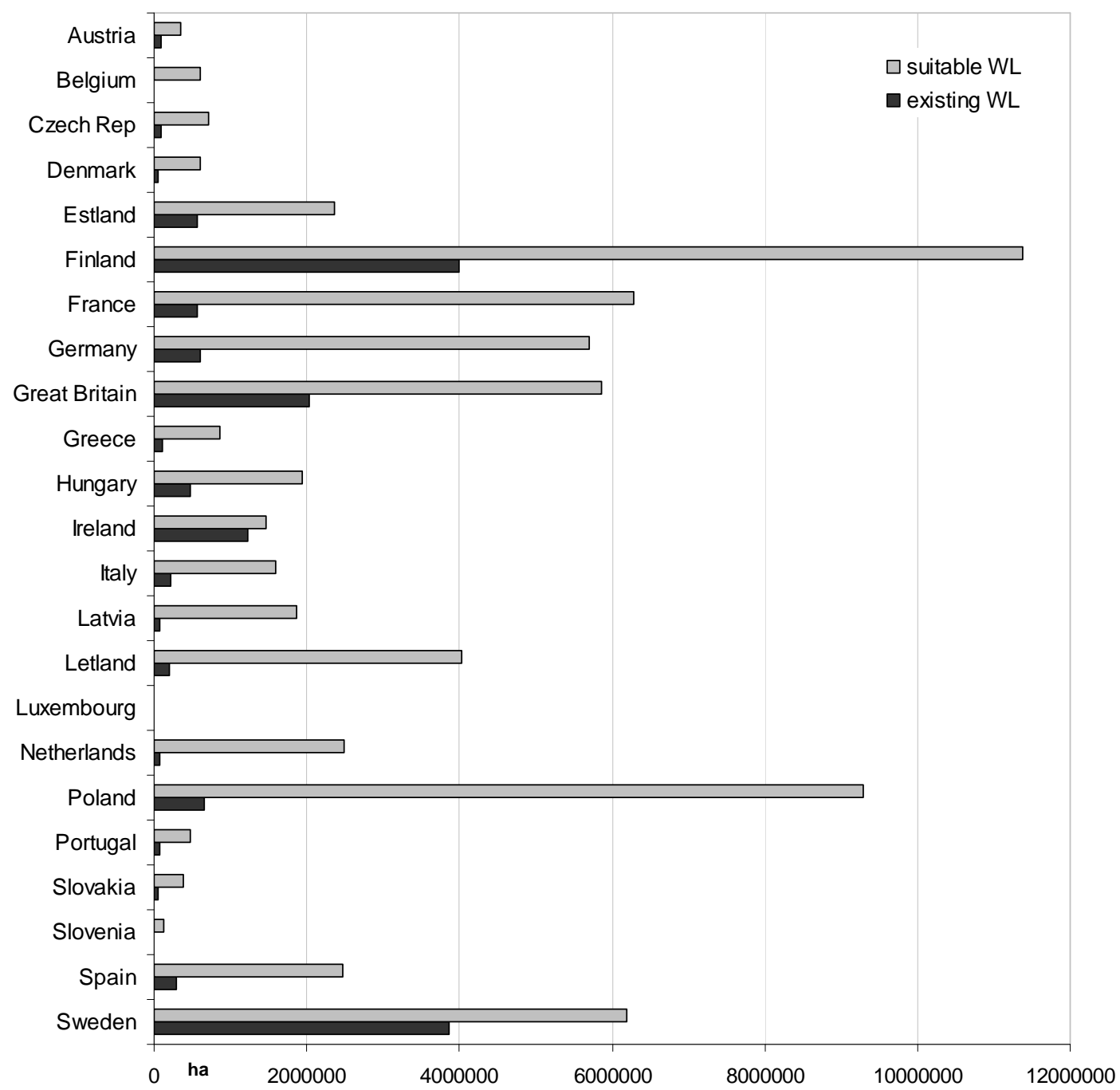

Figure 5. Total wetland area (in 1000 ha) per country distinguished after existing wetlands and suitable restoration sites

Even if not only restricted to formerly existing wetland areas the extent of potential wetland sites also give an impression of wetland loss. Open waters are excluded from the evaluation. Finland and Sweden own by far the most extending existing wetland areas with about 3.8 million ha wetlands. Also Ireland has great amounts of existing wetland areas (about 1.3 million hectares) but less in comparison to the Scandinavian countries. Finland and Sweden also lead in the amount of potential convertible wetland sites. In this category Poland, Great Britain as well as France and to a certain extent Germany as well show high amounts of land suitable for wetland restoration. 
The relationship between wetland areas and country size (see Figure 6 ) displays a different picture: Now Ireland shows the highest wetland rate (PEH) with about $19 \%$ of its country area, followed by Estonia (13\%) and Finland (12\%). Also Sweden and the UK with $8.7 \%$ and $9.25 \%$ of their country size own a high existing wetland rates in comparison to other countries whose amounts lie between $0.03 \%$ (Luxembourg), $0.6 \%$ (Spain), and $5.1 \%$ (Hungary), or $3.2 \% \mathrm{PEH}$ of the country area in the case of Latvia, for example.

Concerning the PCS per country area, Latvia (68\%), the Netherlands (75.6\%), and Estonia $(66 \%)$ have the highest relative potentials. The PCS rate of Finland, Poland, Great Britain, and Ireland amounts to between 31 and $49 \%$ per country area. In this case Denmark, Sweden and Germany have potentials of about 16 to $20 \%$ and the PCS rate of all other countries amount between $5.1 \%$ as lowest rate in Austria and $12.5 \%$ in France.

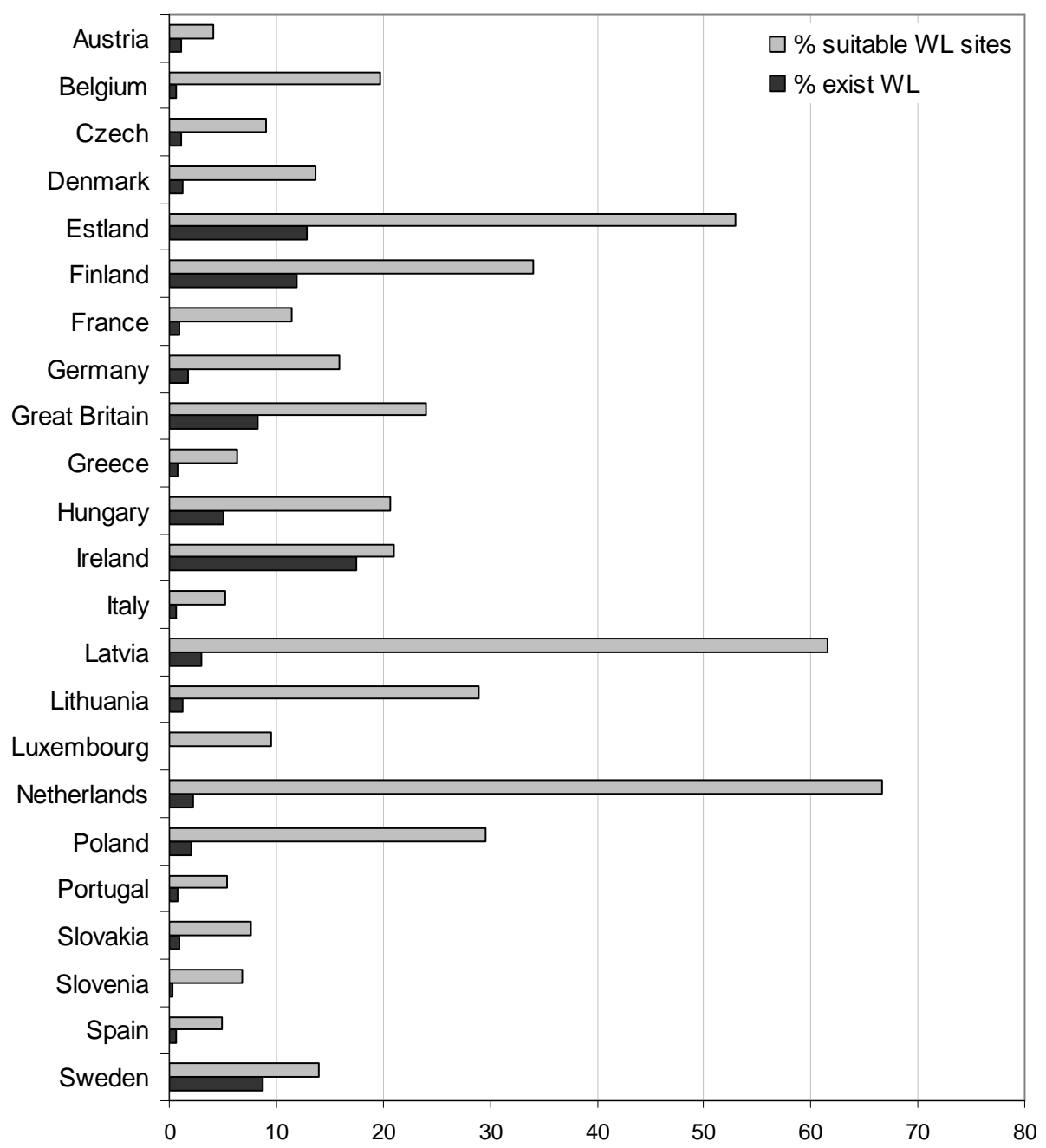

Figure 6. Relative wetland area (\%) per country

Through Swedi the main wetland types peatland (fen/bog), wet forests (alluvial forest/ swamp forest) and wet grassland and its spatial potentials are visualized. Its results make evident that the potential wetland restoration sites are often overlapping. 
This is especially true for peatlands. Moreover, some wetland types might be temporarily successional vegetation states of others within the wetland biotope complexes. Main areas of existing peatland are the Scandinavian countries and Ireland. Here, as well as in Scotland, Eastern Poland and Estland also highest amounts of potential bog areas are found. All other illustrated potential peatland areas may be favorable for fen restoration. Fens can also be created on potential bog areas, but this constraint does not work vice versa. It is remarkable that the formerly extending bog areas of North-Western Germany, that have been mainly drained and exploited during the last centuries, show fen instead of expected bog potentials in Swedi. This might be due to model uncertainties or errors, but can as well be a hint that the bogs have developed under different climatic conditions from the end of the last ice age and are relicts only. The destruction of these bog areas possibly means an unrecoverable demise of the ecosystem. Like wet grasslands also wet forests are found along water courses and in the proximity of other open waters. Especially the swamp forests are constricted to wet soils and to specific climate conditions. Main areas of potential swamp forest sites are therefore found in Central and Eastern Europe but also in the UK. In northern and western European countries the wet forested area does not exceed the peatland areas whereas in Germany and Poland and further south wet forests are the most extending wetland types. Extending areas of potential wet grassland sites are shown in Scandinavia, Estland, and Ireland, but also in Hungary. Wetland areas need to have at least a size of one hectare to be included into the spatial model. Therefore, often reeds along lakeshores are not shown in the results and Finland even counts no wet grasslands even though there are reeds growing along many waters.

Summarizing the total PCS areas distinguished after the main wetland types for the European countries one gets following results: a maximum area of respectively 1329 $200 \mathrm{~km}^{2}, 643300 \mathrm{~km}^{2}$ and $305700 \mathrm{~km}^{2}$ could be potentially used for additional bog, additional fen as well as additional wet forest creation. It must be noted that these data are no absolute numbers, but moreover provide an informative basis of potential wetland restoration area.

\section{Discussion}

There is a growing demand of policy makers and researchers for high-accuracy landscape information at the European level. Despite numerous data on land use in Europe, a detailed analysis of the distribution of wetlands and potential restoration sites has been lacking so far. We developed a detailed wetland distribution map in European scale with high spatial resolution. Not only does it distinguish between different wetland types but also between existing and potential convertible wetland restoration sites; information that has not been available before. Whereas the evaluation of existing wetlands relies on a cross-compilation of existing spatial datasets, the potential wetland restoration sites are determined by definition of flexible knowledge rules in combination with geographical data. The orientation towards physical parameters and the allowance of overlapping wetland types characterizes the Swedi model. The detailed spatially explicit wetland classification of Swedi allows connections to other habitat databases, for example EUNIS, as well.

The accuracy of Swedi is strongly restricted by the availability and quality of geographical data. For example, the soil information is generally poor and often misleading from the standpoint of wetland functionality. The same holds for the 
elevation and slope data. Also the water factor is only indirectly integrated into the model through climate and soil data. As long as these detailed Pan-European data are unavailable provides Swedi a static estimation of wetland potentials suitable for broad scale studies that may be analyzed at landscape scale in more detail. The utilization of GIS makes the methodology highly applicable and easily to improve concerning data sources.

The accuracy assessment showed uncertainties in the wetland size and extent that can be explained through base data uncertainties but also through differences in wetland definition and its assignment. Varying analogies in accuracy of different wetland types is more a reason of scarce and inhomogeneous reference data and less of dissimilar modeling precision. Due to the fact that with Swedi only those wetlands with an area extent of more than 1 ha are displayed, the total wetland distribution may be underestimated. Many wetlands, especially those in central and southern Europe, are very small-sized and its implementation in broad scale maps is still not realized. However, we found no differences in accuracy between northern and southern wetlands. Another uncertainty is the state of the ecosystem of the existing wetlands. In Swedi we are not able to make statements about the naturalness of the site. Nevertheless, the comparison of Swedi with independent datasets of wetland biotopes proved high accuracy of the existing wetland sites in the Swedi model and the area extent is mainly reproduced within the uncertainty range.

The direct use of country aggregated Swedi data by simple polygon measurement as shown in the results section should be regarded with caution. The data give useful results but the European scale should be used with care for area estimation because it can give strongly biased results. In principle, the direct use of such data for estimation is only acceptable when no other data are available (Gallego \& Bamps, 2008). And for the spatially explicit estimation of wetland distribution no other homogeneous data exist in Europe.

The knowledge of the extent and distribution of wetlands is important for a variety of applications. This study applies an empirical distribution model to wetland ecosystems in European scale. These data can be used as ground information for further studies, for example helping to locate sites suitable for renaturation programs, or for the introduction of faunistic corridors respecting the Natura 2000 network of sites. The application of the model in nature conservation issues favours the success in regional conservation planning. The Swedi model on the other hand is meant to be integrated into the economic optimization EUFASOM model to evaluate the economic wetland potentials per EU-country (Schneider et al., 2008). The promotion of bioenergy plantations in the context of climate change mitigation policies constitutes a great challenge to nature conservation, because land use changes could threaten the availability of land for nature reserves and would lead to further biotope loss. By integrating the spatially explicit biotope information of Swedi into the economic land use model EUFASOM, the costs and potentials of different land utilizations as well as optimal conservation opportunities are evaluated.

Furthermore, so far Swedi builds the base data for European biodiversity studies of endangered wetland species that are analyzed for systematic conservation planning options. It is of utmost importance to provide accurate base data for the management and planning of conservation areas. This study offers some first guidelines but is also intended for an impulse of discussion on improvements of such data. The next enhancing step of Swedi besides base data refinements is to make this static extraction 
tool dynamic through the integration of hydrologic parameters for questions concerning climate change, conservation and land use planning options.

Acknowledgements. This study has been financed by the EU-funded project GEOBENE (Global Earth Observation - Benefit Estimation: Now, Next, and Emerging FP6).

\section{REFERENCES}

[1] Araújo, M.B., Pearson, R.G., Thuiller, W., Erhard, M. (2005): Validation of speciesclimate impact models under climate change. - Global Change Biology 11: 1504-1513.

[2] Aselmann, I., Crutzen, P.J. (1989): Global distribution of natural freshwater wetlands and rice paddies, their net primary productivity, seasonality and possible methane emissions. - Journal of Atmospheric Chemistry 8 (4): 307-358.

[3] Bernard, P. (1994): Les zones humides; rapport d'évaluation. Comité interministériel de l'évaluation des politiques publiques. Commissariat au Plan. - La Documentation Francaise, Paris.

[4] BfN (ed.) (2004): Explanatory Text to the Map of the Natural Vegetation of Europe. Landwirtschaftsverlag, Münster.

[5] Blume, H.-P., Brümmer, G.W., Schwertmann, U., Horn, R., Kögel-Knaber, I., Stahr, K., Auerswald, K., Beyer, L., Hartmann, A., Litz, L., Scheinost, A., Stanjek, H., Welp, G., Wilke, B.-M. (2002): Scheffer / Schachtschabel. Lehrbuch der Bodenkunde, $15^{\text {th }}$ edition. - Ferdinand Enke Verlag, Stuttgart.

[6] Bohn, U., Neuhäusel, R., with contributions by Gollub, G., Hettwer, C., Neuhäuslová, Z., Raus, T., Schlüter, H., Weber, H. (2003): Karte der natürlichen Vegetation Europas / Map of the Natural Vegetation of Europe. Scale 1 : 2500 000. - Landwirtschaftsverlag, Münster.

[7] Brinson, M.M. (1993): Hydrogeomorphic Classification for Wetlands. - US Army Corps of Engieneers, Wetland Research Program. TR: WRP-DE-4, Washington DC.

[8] Chefaoui, R.M., Lobo, J.M. (2008): Assessing the effects of pseudo-absences on predictive distribution model performance. - Ecological Modelling 210: 478-486.

[9] Cowardin, L.M., Carter, V., Golet, F.C., LaRoe, E.T. (1979): Classification of wetlands and deepwater habitats of the United States. - US Fish \& Wildlife Service, Washington DC.

[10] Dahl, T.E. (2006): Status and trends of wetlands in the conterminous United States 1998 to 2004. - US Department of the Interior, Fish and Wildlife Service, Washington DC.

[11] Dierssen, K., Dierssen, B. (2001): Ökosysteme Mitteleuropas „Moore“. - Ulmer, Stuttgart.

[12] EEA (ed.). (1995): CORINE Land Cover. Part 2: Nomenclature. - Available via http://reports.eea.europa.eu/CORO_landcover/en.

[13] EEA (ed.). (2000a): CORINE Biotopes Database. - Available via http://dataservice.eea.eu.int/dataservice.

[14] EEA (ed.). (2000b): CORINE Land Cover 2000 Database, 100 m. - Available via http://dataservice.eea.eu.int/dataservice.

[15] EEA (ed.). (2002): The Biogeographical Regions Map of Europe. - European Environment Agency, Copenhagen. Available via http://dataservice.eea.eu.int/dataservice.

[16] EEA (ed.). (2006): The thematic accuracy of Corine Land Cover 2000. Assessment using LUCAS (land use/cover area frame statistical survey). - European Environment Agency, Copenhagen. 
[17] Ellenberg H., Arndt, U., Bretthauer, R., Ruthsatz, B., Steubing, L. (1991): Biological Monitoring - Signals from the environment. - GATE publication Vieweg, Braunschweig.

[18] Ellenberg, H. (1996): Vegetation Mitteleuropas mit den Alpen, $5^{\text {th }}$ edition. - Ulmer, Stuttgart.

[19] European Commission (1991): CORINE biotopes. The design, compilation and use of inventory of sites of major importance for nature conservation in the European Community. - EUR 13231 EN. Brussels.

[20] European Topic Centre on Biological Diversity (ed.) (1993-2006): Introduction to EUNIS database. - Available via http://eunis.eea.europa.eu/.

[21] Franklin, J. (1995): Predictive vegetation mapping: geographic modelling of biospatial patterns in relation to environmental gradients. - Prog. Phys. Geogr. 19: 474-499.

[22] Franklin, J.F., Swanson, M.E. (2007): Forest Landscape Structure, Degradation and Condition: Some Commentary and Fundamental Principles. pp. 131-145. - In: Lindenmayer, D.B., Hobbs, R.J. (eds.) Managing and Designing Landscapes for Conservation: Moving from Perspectives to Principles. Conservation Science and Practice Series 1, Blackwell Publishing, Oxford.

[23] Gallego, J., Bamps, C. (2008): Using CORINE land cover and the point survey LUCAS for area estimation. - International Journal of Applied Earth Observation and Geoinformation 10(4): 467-475.

[24] Guisan, A., Zimmermann, N. E. (2000): Predictive habitat distribution models in ecology. - Ecological Modelling 135: 147-186.

[25] Helmschrot, J., Flügel, W.-A. (2002): Land use characterization and change detection analysis for hydrological model parameterization of large scale afforested areas using remote sensing. - Physics and Chemistry of the Earth 27: 711-718.

[26] Joint Research Centre (ed.) (2000): Global Land Cover - Available via http://wwwgem.jrc.it/glc2000/.

[27] Joint Research Centre (2004): European Soil Database (v 2.0), - European Soil Bureau Network and the European Commission, EUR 19945 EN.

[28] Klijn, J.A. (2002): Driving forces behind landscape transformation in Europe, from a conceptual approach to policy options. pp. 201-218. - In: Jongmann, R.H.G. (ed.) The new dimensions of the European landscape. - Wageningen UR Frontis Series, Springer, Berlin.

[29] Kuntze, H., Roeschmann, G., Schwerdtfeger, G. (1994): Bodenkunde, $5^{\text {th }}$ edition. - UTB, Verlag Eugen Ulmer, Stuttgart.

[30] Lehner, B., Döll, P. (2004): Development and validation of a global database of lakes, reservoirs and wetlands. - Journal of Hydrology 296(1-4): 1-22.

[31] LIFE (ed.) (2007): Europe's wetlands - status and trends. - LIFE Focus: 3-11.

[32] Lyon, J. (2001): Wetland Landscape Characterization: GIS, Remote Sensing, and Image Analysis. - Ann Arbor Press, Chelsea, MI, USA.

[33] Matthews, E., Fung, I. (1987): Methane Emission from Natural Wetlands: Global Distribution, Area, and Environmental Characteristics of Sources. - Global Biogeochemical Cycles GBCYEP 1(1): 61-86.

[34] Merot, P., Squividant, H., Aurousseau, P., Hefting, M., Burt, T., Maitr, V., Kruk, M., Butturini, A., Thenail, C., Viaud, V. (2003): Testing a climato-topographic index for predicting wetlands distribution along an European climate gradient. - Ecological Modelling 163(1-2): 51-71.

[35] Miller, J., Franklin, J., Aspinall, R. (2007): Incorporating spatial dependence in predictive vegetation models. - Ecological Modelling 202: 225-242.

[36] Mitsch, W.J. (ed.) (1994): Global Wetlands: Old World and New. - Elsevier, Amsterdam. 
[37] Moss, D., Wyatt, B.K. (1994): The CORINE Biotopes Project: a database for conservation of nature and wildlife in the European Community. - Applied Geography 14: 327-349.

[38] Moss, D., Davies, C., Roy, D. (1996): CORINE Biotopes sites-database. Status and Perspectives 1995. - Topic Report No 27/1996. Available via EEA: http://www.eea.europa.eu/.

[39] Moss, D., Davies, C. (2002a): Cross-references between EUNIS habitat classification and the Habitats Directive. - European Topic Centre on Nature Protection and Biodiversity, Paris.

[40] Moss, D., Davies, C. (2002b): Cross-references between the EUNIS habitat classification and the nomenclature of the CORINE land cover. - CEH project No. CC00389.

[41] Mulamoottil, G., Warner, B.G., McBean, E.A. (1996): Wetlands: Environmental Gradients, Boundaries and Buffers. - Lewis Publishers, New York.

[42] Nivet, C., Frazier, S. (2004): A review of European wetland inventory information. Report prepared in the framework of "A pilot study towards a Pan-European wetland inventory". - In: Taylor, A.R.D. and van Eerden, M. (eds.). Wetlands International (RAMSAR).

[43] Pott, R., Remy, D. (2000): Gewässer des Binnenlandes. - Ulmer, Stuttgart.

[44] RAMSAR Bureau. The Ramsar Convention on Wetlands. Key Documents. - Available via http://www.ramsar.org/index_key_docs.htm.

[45] RAMSAR Bureau (2008): The list of Wetlands of International Importance. - Gland, Switzerland. Available via http://www.ramsar.org.

[46] Sanderson, M.G. (2001): Global Distribution of Freshwater Wetlands for use in STOCHEM. - Hadley Centre Technical Note 32.

[47] Schneider, U.A., Balkovic, J., De Cara, S., Franklin, O., Fritz, S., Havlik, P., Huck, I., Jantke, K., Kallio, A.M.I., Kraxner, F., Moiseyev, A., Obersteiner, M., Ramos, C.I., Schleupner, C., Schmid, E., Schwab, D., Skalsky, R. (2008): The European Forest and Agricultural Sector Optimization Model - EUFASOM. - FNU-156, Hamburg University and Centre for Marine and Atmospheric Science, Hamburg.

[48] Schultlink, G., Van Vliet, R. (1997): Wetland identification and protection: North American and European policy Perspectives. - Departement of Resource Development. Michigan State University. Available via http://rdservl.rd.msu.edu/wetlands/ wims/wims_nort.doc.

[49] Scott, J.M., Tear, T.H. (2007): What are we conserving? Establishing Multiscale Conservation Goals and Objectives in the Face of Global Threats. p. 494-510. - In: Lindenmayer, D.B., Hobbs, R.J. (eds.) Managing and Designing Landscapes for Conservation: Moving from Perspectives to Principles. Conservation Science and Practice Series 1, Blackwell Publishing, Oxford.

[50] Stillwell-Soller, L.M., Klinger, L.F., Pollard, D., Thompson, S.L. (1995): The Global Distribution of Freshwater Wetlands. TN-416STR. National Center for Atmospheric Research, Boulder, Colorado. - $\quad$ Available via http://www.scd.ucar.edu/iag/staff/lana/wetlands/.

[51] Succow, M., Jeschke, L. (1990): Moore in der Landschaft. - Urania, Leipzig, Germany.

[52] Succow, M., H. Joosten (eds.). (2001): Landschaftsökologische Moorkunde. - E. Schweitzerbert'sche Verlagsbuchhandlung, Stuttgart.

[53] Tsihrintzis, V.A., John, D.L., Tremblay, P.J. (1998): Hydrodynamic Modeling of Wetlands for Flood Detention. - Water Resources Management Journal 12(4): 251-269.

[54] USGS (ed.) (1996): GTOPO30. - Available via http://www.edcdaac.usgs.gov/gtopo30/gtopo30.html.

[55] Verbyla, D.L., Litaitis, J.A. (1989): Resampling methods for evaluating classification accuracy of wildlife habitat models. - Environmental Management 13: 783-787. 
[56] Walter, H., Breckle, S.W. (1999): Vegetation und Klimazonen (7 $7^{\text {th }}$ ed.). - Ulmer, Stuttgart.

[57] Walter, H., Lieth, H. (1967): Klimadiagramm-Weltatlas ( ${ }^{\text {rd }}$ ed.). - Fischer, Jena.

[58] Walter, H., Walter, E. (1953): Einige allgemeine Ergebnisse unserer Forschungsreise nach SW-Afrika 1952/53: Das Gesetz der relativen Standortkonstanz; das Wesen der Pflanzengemeinschaften. - Berichte der Deutschen Botanischen Gesellschaft 66: 228236.

[59] Wascher, D.M. (2000): Agri-environmental indicators for sustainable agriculture in Europe. - European Centre for Nature Conservation, Tilburg. ECNC Technical Report Series, Wageningen, The Netherlands.

[60] Wheeler, B.D., Shaw, S.C., Fojt, J., Robertson, R.A. (eds.) (1995): Restoration of temperate wetlands. - John Wiley \& Sons, New York.

[61] Wiens, J.A. (2007): Does Conservation need Landscape Ecology? A Perspective from both sides of the Divide. p. 479-493. - In: Lindenmayer, D.B., Hobbs, R.J. (eds.) Managing and Designing Landscapes for Conservation: Moving from Perspectives to Principles. Conservation Science and Practice Series 1, Blackwell Publishing, Oxford. 